\title{
A eleição de 2002
}

\author{
Rubens Figueiredo \\ Ciro Coutinho
}

CEPAC - Pesquisa e Comunicação

\section{Resumo}

O artigo analisa a campanha presidencial de 2002 a partir dos resultados das pesquisas de intenção de voto divulgadas na mídia, da propaganda eleitoral gratuita na televisão e do contexto político que resultou na vitória do candidato do Partido dos Trabalhadores, Luís Inácio Lula da Silva.

Palavras-chave: eleições, pesquisas de opinião, propaganda eleitoral, televisão.

\begin{abstract}
The article analyses the 2002 presidential campaign considering the results of electoral polls published in mass media, the electoral advertising, defined by law on television, and the political context that have resulted in the victory of Labor's Party candidate, Luís Inácio Lula da Silva.
\end{abstract}

Key words: elections, public opinion polls, electoral advertising, television. 
Nenhuma eleição brasileira gerou tamanha quantidade de pesquisas como a disputa pela Presidência da República em 2002. Entre janeiro e início de outubro, foram divulgados nada menos que 70 resultados de levantamentos realizados pelos principais institutos de pesquisa do país: 23 do Ibope, 15 do Datafolha, 12 do Instituto Sensus e 20 do Vox Populi. Evidentemente, cada divulgação foi devidamente acompanhada de análises, "projeções" e comentários de jornalistas, sociólogos, cientistas políticos, economistas, publicitários, políticos e, às vezes, até de psicanalistas.

Além disso, conforme observaram alguns analistas, como por exemplo Jânio de Freitas, do jornal Folha de S. Paulo, as pesquisas também podem ter desempenhado outro papel nestas eleições: fornecer informações privilegiadas para que alguns bancos e corretoras pudessem tomar decisões em relação a seus investimentos na Bolsa de Valores (FREITAS, 2002). Esta suspeita fez com que, em 16 de julho de 2002, a Comissão de Valores Mobiliários (CVM) criasse uma legislação específica para regular a divulgação de sondagens realizadas a pedido de instituições do mercado financeiro.

Outro destaque da campanha eleitoral de 2002 foi a enorme cobertura realizada pela televisão. Além da propaganda gratuita partidária e do horário eleitoral gratuito, velhas conhecidas dos eleitores, as emissoras ofereceram um grande espaço aos principais candidatos: até abril, Luís Inácio Lula da Silva (Partido dos Trabalhadores), José Serra (Partido da Social Democracia Brasileira), Anthony Garotinho (Partido Socialista Brasileiro) e Ciro Gomes (Partido Popular Socialista) apareceram em mais de 20 ocasiões em atrações de entretenimento, como o programa "Domingo Legal" do SBT e, entre maio e outubro (apenas antes do primeiro turno, portanto), mais de 70 vezes em programas de caráter predominantemente jornalístico (MATTOS, 2002). A Rede Globo, por exemplo, inovou em sua cobertura, realizando entrevistas individuais ao vivo no Jornal Nacional, que atingiram uma média de 40 pontos na medição de audiência realizada pelo Ibope, ou seja, cerca de 2,1 milhões de telespectadores por minuto em todo o Brasil.

Tomando por base as pesquisas e a cobertura da imprensa, este artigo procura analisar como se desenvolveu esta campanha, quais foram as estratégias dos principais candidatos e como as pesquisas e a propaganda eleitoral gratuita interferiram nos acontecimentos que culminaram com a eleição do presidente Luís Inácio Lula da Silva. 


\section{Opinião pública: o desgaste do governo $\mathrm{FHC}$ e o desejo de mudança}

A análise do contexto em que se desenvolveu a eleição de 2002 deve considerar que o Brasil vinha de duas eleições decididas em primeiro turno a favor de Fernando Henrique Cardoso (PSDB). Em parte devido ao extenso período no poder, a popularidade de seu governo foi corroída no segundo mandato, quando ocorreram, em 1999, a crise cambial, com a conseqüente desvalorização do Real e, em 2001, o racionamento de energia, criando um cenário difícil para o candidato tucano José Serra na disputa eleitoral. De acordo com o Instituto Datafolha, em outubro de 2002 a avaliação positiva (respostas "ótimo/bom") do governo FHC era de $23 \%$, bem inferior à obtida em setembro de 1998 , de $43 \%$, pouco antes de sua reeleição.

Apesar do cenário predominantemente desfavorável, os números das sondagens não traziam apenas notícias ruins para o governo. Em junho, uma pesquisa realizada pelo Ibope a pedido da Confederação Nacional da Indústria (CNI) mostrava que uma parcela expressiva da população reconhecia que, após a implantação do Real, a situação havia melhorado "um pouco/muito" na educação (53\%), na saúde (45\%) e nos transportes (42\%).

Ainda assim, $65 \%$ dos brasileiros consideravam que a geração de emprego havia piorado "um pouco/muito" e, na questão da segurança, 54\% avaliavam negativamente o governo. Outra questão desta mesma sondagem revelava este clima dominante na opinião pública nacional: $52 \%$ dos entrevistados disseram que não votariam de jeito nenhum em um candidato que representasse a continuidade da política de $\mathrm{FHC} ; 44 \%$ afirmaram que certamente votariam ou poderiam votar; $5 \%$ não responderam. Este desejo de mudança estava claro pela liderança de Lula nas pesquisas de todos os institutos e na estratégia de todos os principais candidatos, inclusive do candidato oficial do governo, José Serra, que, de forma inequívoca, não assumiu sua condição de candidato governista.

A vontade de mudança no final do governo Fernando Henrique era, entretanto, diferente daquela que existia no término do governo Sarney, em 1989. Naquele ano, o país enfrentava índices mensais de inflação de dois dígitos e realizava sua primeira eleição presidencial direta desde 1961. A aprovação ao Executivo era de apenas $9 \%$, a desaprovação atingia $56 \%$ e a expectativa de que fosse eleito alguém capaz de mudar radicalmente a situação e "salvar" o país era enorme. Este quadro culminou com a eleição de Fernando Collor de Mello. 
A gestão de Fernando Collor de Mello, no entanto, foi uma decepção para os brasileiros e os escândalos de corrupção em seu governo fizeram com que, apenas dois anos e meio depois de assumir, o ex-governador de Alagoas fosse avaliado negativamente pela maioria da população ${ }^{1}$. A crise política terminou com sua renúncia e com a posse do vice-presidente, Itamar Franco, que realizou um governo bem avaliado, sobretudo pela implantação do Plano Real, conduzida pelo então Ministro da Fazenda, Fernando Henrique Cardoso.

\section{Tabela 1}

Avaliação presidencial para o período 1990-2002

\begin{tabular}{|c|c|c|c|}
\hline \multirow{2}{*}{ Presidente } & \multicolumn{3}{|c|}{ Avaliação } \\
\cline { 2 - 4 } & Ótimo/bom & Regular & Ruim/péssimo \\
\hline José Sarney (mar/90) & $9 \%$ & $34 \%$ & $56 \%$ \\
\hline Fernando Collor (set/92) & $9 \%$ & $21 \%$ & $68 \%$ \\
\hline Itamar Franco (dez/94) & $41 \%$ & $48 \%$ & $8 \%$ \\
\hline FHC (set/98) & $43 \%$ & $37 \%$ & $17 \%$ \\
\hline FHC (out/02) & $23 \%$ & $42 \%$ & $32 \%$ \\
\hline
\end{tabular}

Fonte: Instituto Datafolha.

Diferentemente, em 2002, o governo Fernando Henrique apresentava uma avaliação predominantemente negativa, mas algumas conquistas de seu governo, como a estabilidade econômica, eram reconhecidas não apenas pela população, mas por analistas políticos e econômicos (LAMOUNIER e FIGUEIREDO, 2002). Além disso, as pesquisas mostravam que, comparativamente, a imagem pessoal do presidente era melhor do que a imagem dos presidentes anteriores e dos principais candidatos que concorreram à sua sucessão. O Ibope, por exemplo, em pesquisa realizada em setembro de 2002, detectou que $71 \%$ dos brasileiros achavam que o presidente FHC tinha "habilidade política"; 81\%, que tinha "inteligência"; 68\% julgavam que tinha "preparo" e 70\% consideravam que o presidente possuía "respeito internacional". Estes percentuais eram ainda superiores aos dos quatro principais candidatos ao Planalto, que também foram avaliados segundo estes aspectos de sua imagem pessoal pelos entrevistados.

\footnotetext{
${ }^{1}$ Segundo o Instituto Datafolha, 68\% avaliavam Fernando Collor como "ruim ou péssimo".
} 
Tabela 2

Avaliação de FHC e dos candidatos à Presidência - IBOPE- CNI, 2002

\begin{tabular}{|c|c|c|c|c|c|c|c|c|c|c|c|c|}
\hline \multirow[t]{2}{*}{$\begin{array}{l}\text { Atributo/ } \\
\text { Político }\end{array}$} & \multicolumn{3}{|c|}{ Habilidade Política } & \multicolumn{3}{|c|}{ Inteligência } & \multicolumn{3}{|c|}{ Preparo } & \multicolumn{3}{|c|}{$\begin{array}{c}\text { Respeito } \\
\text { Internacional }\end{array}$} \\
\hline & Tem & $\begin{array}{l}\text { Não } \\
\text { tem }\end{array}$ & $\begin{array}{l}\text { NS } \\
\text { INO }\end{array}$ & Tem & $\begin{array}{l}\text { Não } \\
\text { tem }\end{array}$ & $\begin{array}{l}\text { NS } \\
\text { INO }\end{array}$ & Tem & $\begin{array}{l}\text { Não } \\
\text { tem }\end{array}$ & $\begin{array}{l}\text { NS } \\
\text { INO }\end{array}$ & Tem & $\begin{array}{l}\text { Não } \\
\text { tem }\end{array}$ & $\begin{array}{l}\text { NS } \\
\text { INO }\end{array}$ \\
\hline $\mathrm{FHC}$ & $71 \%$ & $20 \%$ & $9 \%$ & $81 \%$ & $13 \%$ & $6 \%$ & $68 \%$ & $24 \%$ & $8 \%$ & $70 \%$ & $19 \%$ & $11 \%$ \\
\hline Lula & $57 \%$ & $32 \%$ & $11 \%$ & $66 \%$ & $25 \%$ & $9 \%$ & $50 \%$ & $38 \%$ & $12 \%$ & $43 \%$ & $39 \%$ & $18 \%$ \\
\hline José Serra & $64 \%$ & $22 \%$ & $13 \%$ & $77 \%$ & $14 \%$ & $9 \%$ & $61 \%$ & $27 \%$ & $12 \%$ & $58 \%$ & $23 \%$ & $19 \%$ \\
\hline Garotinho & $50 \%$ & $34 \%$ & $16 \%$ & $64 \%$ & $24 \%$ & $12 \%$ & $44 \%$ & $41 \%$ & $15 \%$ & $35 \%$ & $42 \%$ & $23 \%$ \\
\hline Ciro Gomes & $57 \%$ & $29 \%$ & $14 \%$ & $68 \%$ & $20 \%$ & $12 \%$ & $53 \%$ & $33 \%$ & $14 \%$ & $42 \%$ & $35 \%$ & $22 \%$ \\
\hline
\end{tabular}

Pergunta: "Pensando em (nome do candidato), queria que o(a) sr(a) me dissesse, para cada atributo, se ele tem ou não tem cada um deles?"

Fonte: Pesquisa Ibope-CNI, setembro de 2002.

Outra pesquisa, realizada pelo Datafolha após a eleição, em dezembro de 2002, mostrou que $18 \%$ dos brasileiros apontavam espontaneamente FHC como o melhor presidente que o país já teve, uma porcentagem próxima, mas mais elevada, à avaliação obtida por Getúlio Vargas (14\%). Mesmo considerando o fato de que o presidente "tucano" estava em evidência, os números mostram que sua imagem pessoal foi preservada, apesar das crises que enfrentou e das críticas da oposição que, uma vez vitoriosa, tentou desfazer a idéia de caos que havia ajudado a criar durante o período eleitoral.

O clima da opinião pública mostrava, portanto, um governo relativamente desgastado, mas um presidente altamente prestigiado. Pode-se dizer, neste sentido, que a população queria mudanças, mas não desprezava os avanços que haviam sido conseguidos pelo governo FHC. Lula e sua equipe entenderam o recado e souberam dizer na campanha presidencial o que o eleitorado queria ouvir. 


\section{A propaganda institucional partidária alavanca candidaturas}

Como já foi destacado anteriormente, a imprensa brasileira realizou uma cobertura abrangente das eleições em 2002. No caso da televisão, isto ocorreu de modo ainda mais intenso. O espaço dedicado aos candidatos em programas de entretenimento e de jornalismo ajudou os eleitores a conhecerem melhor os políticos e suas propostas. Entretanto, foram o horário partidário e o horário eleitoral gratuito que causaram alterações significativas nos percentuais de votos dos candidatos e aumentaram o interesse pelas pesquisas na campanha.

Foram 16 horas de publicidade institucional ocupadas pelos partidos com representação no Congresso Nacional no primeiro semestre do ano. Depois, os 18.151 candidatos que disputavam as 1.600 vagas nos Executivos e Legislativos federal e estaduais tiveram mais 87 horas e trinta minutos no rádio e na televisão durante o período oficial de campanha.

A partir das propagandas partidárias gratuitas, observou-se a ascensão de Roseana Sarney, pré-candidata pelo Partido da Frente Liberal. Na época governadora do Maranhão, ela havia começado a aparecer nos comerciais do partido em setembro de 2001, apresentando a imagem de uma mulher moderna, sensível aos problemas sociais e com alta aprovação da população maranhense à sua gestão. Sem apresentar propostas ou assumir explicitamente ser candidata à Presidência nas primeiras aparições, a filha do ex-presidente José Sarney tornou-se capa das principais revistas semanais e alvo de críticas como as do jornalista Eugênio Bucci: "Já que tudo é imagem, alguém deveria proclamar, de uma vez, que a publicidade suplantou o jornalismo na função de mediar os debates públicos. Sem publicidade, não há democracia. Pelo menos, não há eleição. O tal 'fator' Roseana está aí para comprovar. Algumas centenas de inserções de comerciais do PFL na TV transformaram a governadora do Maranhão na nova marca registrada da campanha presidencial. Não que ela seja uma liderança carismática. Todos sabem que o feito de sua própria marca não é dela, mas dos filminhos publicitários" (BUCCl, 2001, p.2).

A imagem pessoal de Roseana unia beleza, tranqüilidade no falar, um sobrenome conhecido e circunstâncias favoráveis. Era uma novidade política no âmbito nacional e poderia ser o rosto da mudança tão desejada pelos brasileiros. Além disso, segundo pesquisa Ibope-CNI de dezembro de 2001, quando se tratava de política, havia uma imagem muito favorável à atuação das mulheres em comparação à dos homens (Tabela 3). Por fim, ressalte-se ainda que Roseana era uma candidata que dependia fortemente do eleitorado feminino, obtendo naquela pesquisa $61 \%$ de votos entre as mulheres. 


\section{Tabela 3}

Avaliação da atuação de homens e mulheres, segundo o eleitorado, IBOPE, 2001.

\begin{tabular}{|l|c|c|c|c|}
\hline \multicolumn{1}{|c|}{ Característica } & Mulheres & Homens & ambos/nenhum & NS/NO \\
\hline $\begin{array}{l}\text { Mais sensível aos problemas } \\
\text { sociais }\end{array}$ & $72 \%$ & $15 \%$ & $8 \%$ & $5 \%$ \\
\hline Mais organizado & $59 \%$ & $24 \%$ & $12 \%$ & $6 \%$ \\
\hline Mais honesto & $59 \%$ & $12 \%$ & $20 \%$ & $8 \%$ \\
\hline Mais determinado & $48 \%$ & $37 \%$ & $10 \%$ & $5 \%$ \\
\hline Mais realizador & $47 \%$ & $34 \%$ & $12 \%$ & $7 \%$ \\
\hline Mais competente & $44 \%$ & $30 \%$ & $20 \%$ & $6 \%$ \\
\hline Negocia melhor & $36 \%$ & $47 \%$ & $` 11 \%$ & $6 \%$ \\
\hline
\end{tabular}

Pergunta: "Pensando nas diferenças entre as formas dos homens e das mulheres agirem na política e pelo que o(a) $\operatorname{sr}($ a) sabe ou ouve falar, na sua opinião, qual deles costuma ser:"

Fonte: CNI-Ibope, dezembro de 2001.

Não obstante ter sido considerada um "fenômeno" pela imprensa, e chegando a estar tecnicamente empatada com Lula nas pesquisas de intenção de voto do período, a candidatura de Roseana Sarney terminou quando foram descobertos $\mathrm{R} \$ 1,5$ milhão em dinheiro no escritório da empresa Lunus, da qual ela era sócia, dinheiro que foi considerado recurso de campanha. A imagem dos pacotes de $R \$ 50,00$, caprichosamente dispostos em uma mesa, destacada em revistas e na televisão, gerou uma sucessão de versões estapafúrdias para explicar a origem do dinheiro e levantou suspeitas a ponto da governadora desistir da candidatura em abril de 2002. 


\section{Gráfico 1}

Pesquisa Datafolha

Intenção de voto estimulada e única (em \%)

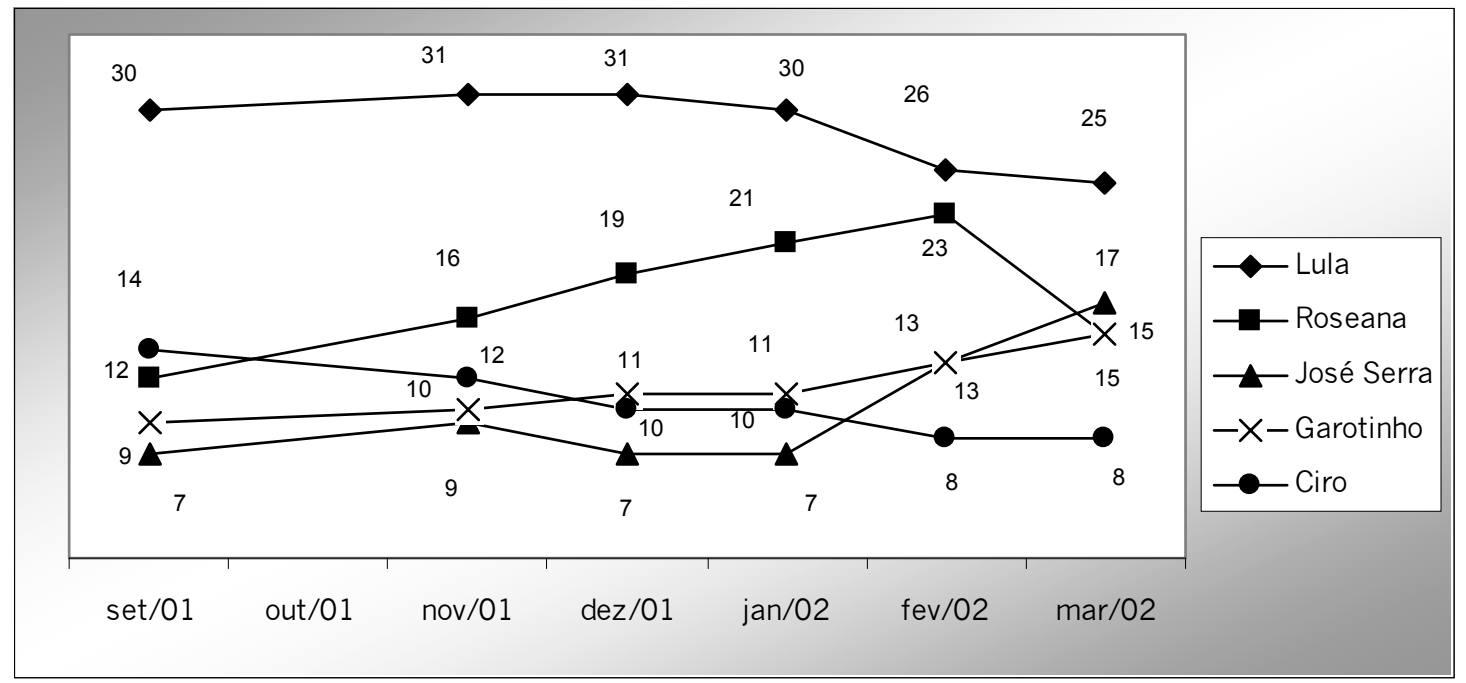

Obs: apenas os candidatos mais citados.

A história da candidatura Roseana Sarney destaca-se por mostrar a clara dependência eleitoral dos políticos frente à mídia, qual seja, um político com uma imagem bem construída na televisão e com espaço na mídia pode credenciar-se para disputar um cargo importante, como é o de Presidente da República. Não obstante, o episódio mostra ainda que apenas isso não basta, pois uma crise de grande proporção na mídia põe fim a qualquer candidatura ou político. Em outras palavras, o "episódio Roseana" representou um exemplo de candidatura "midiática", surgida em função de uma necessidade do eleitorado, mas que também revelou a força do marketing político em um país de partidos fracos, eleitores pouco escolarizados e com uma televisão capaz de criar (e destruir) ídolos da noite para o dia.

Por outro lado, este episódio seria apenas o primeiro de uma série de ascensões e quedas dos principais candidatos - em razão das propagandas partidárias gratuitas - na disputa pelo segundo lugar. Todos os candidatos sentiram os efeitos da veiculação de sua imagem pelas propagandas eleitorais. Anthony Garotinho passou de 12\% a 18\%, após aparecer nos dias 05 e 12 de fevereiro; Serra, de $16 \%$ para $22 \%$, depois do programa em 06 de março; Lula subiu de $32 \%$ para $43 \%$ das intenções de voto, após seu programa em 09 de maio; e Ciro foi de $11 \%$ a 22\%, após sua aparição em 06 de junho (Ibope e Valor Econômico, 08/07/2002). 
Uma medição através de um índice denominado Gross Rating Point (GRP), que leva em consideração o tempo das propagandas e a audiência de acordo com os horários em que são exibidas, confirma as oscilações dos candidatos nas pesquisas de intenção de voto após suas aparições na televisão, conforme mostram os gráficos a seguir:

Gráfico 2

Gross Rating Points X Intenção de voto em Lula

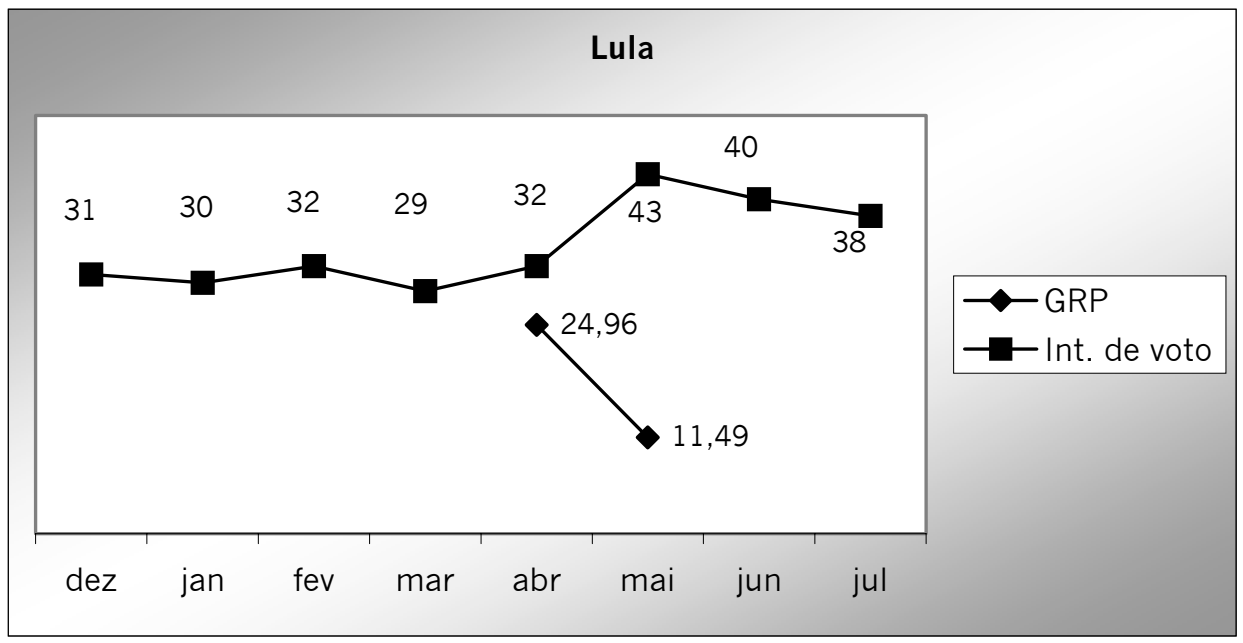

Gráfico 3

Gross Rating Points $X$ Intenção de voto em Serra

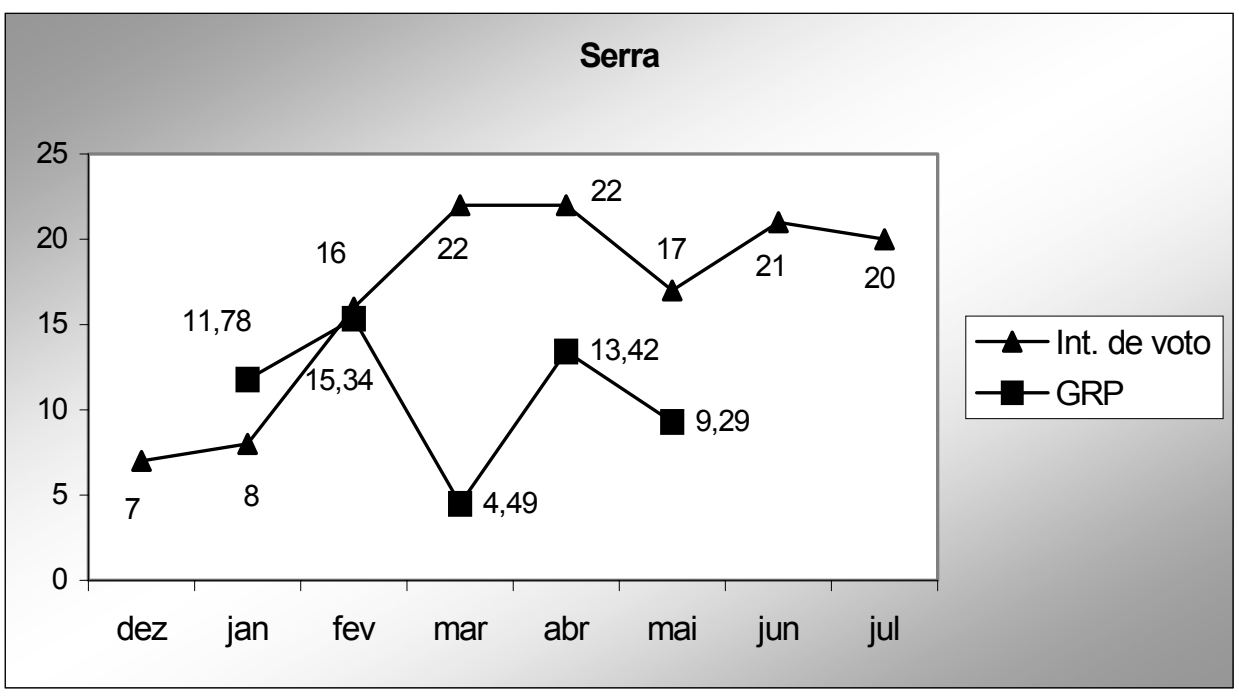




\section{Gráfico 4}

Gross Rating Points $X$ Intenção de voto em Garotinho

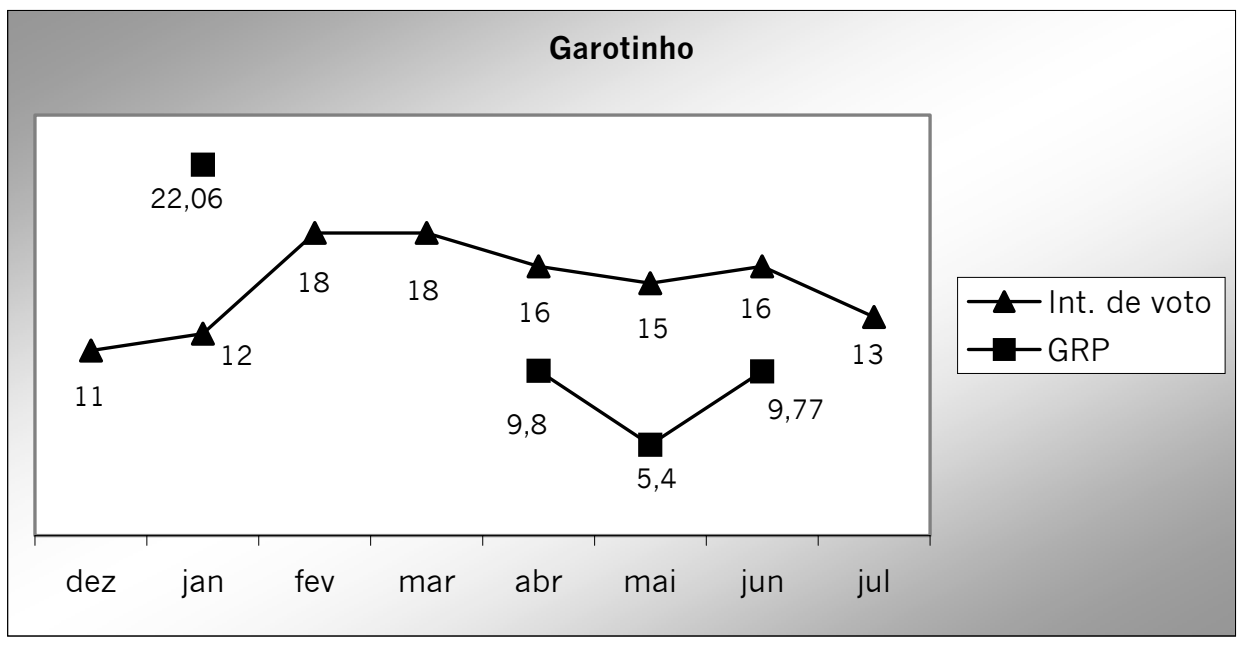

Gráfico 5

Gross Rating Points $X$ Intenção de voto em Ciro

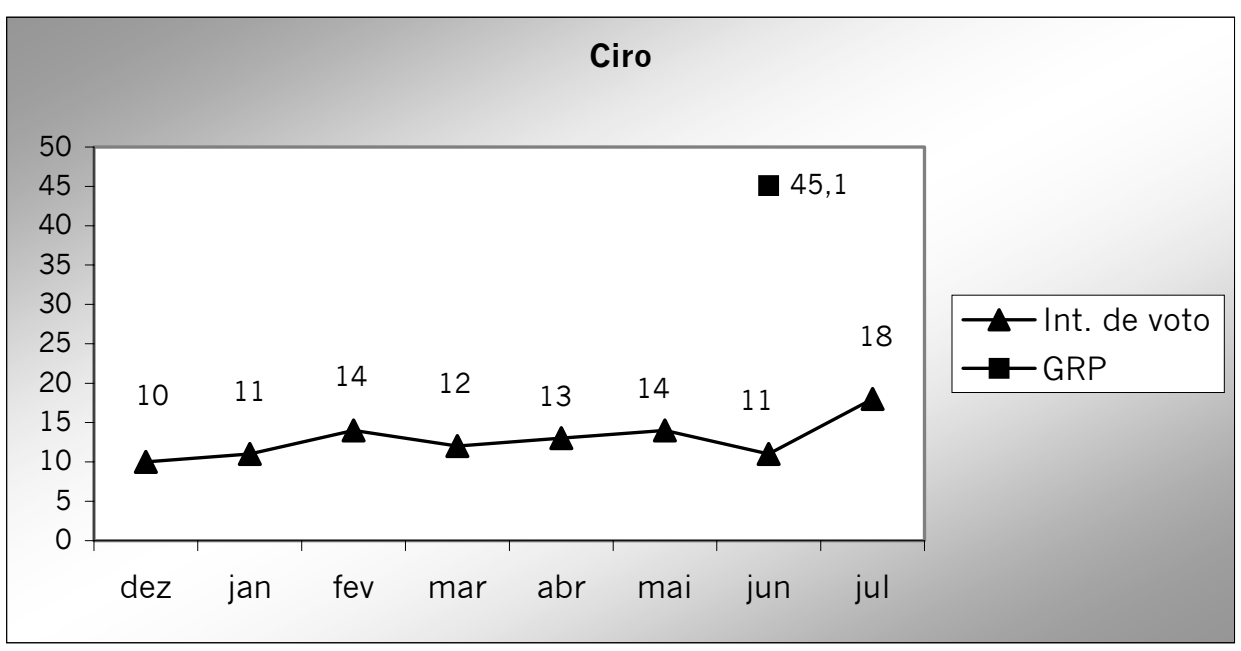


O grande poder exercido pela televisão e seus possíveis efeitos sobre a política têm gerado inúmeros debates na literatura especializada. Um dos aspectos que tem sido abordado dentro deste campo investiga especificamente a influência exercida pela televisão nos processos eleitorais. Lourenço (2001), por exemplo, analisa o horário eleitoral gratuito e sua relação com os percentuais de intenção de voto na disputa presidencial e pelo governo do Estado de São Paulo em 1998 e conclui que o efeito das propagandas é maior sobre os eleitores indecisos. Já Mungham (1996), abordando especificamente o caso da Grã-Bretanha, afirma que o comportamento dos partidos alterou-se em busca de uma adequação ao formato televisivo e à sua audiência. Embora nenhum dos dois autores mencione especificamente o índice GRP, que é um medidor de audiência mais sofisticado, abordam de maneira aprofundada como a televisão influencia o comportamento político na atualidade.

No caso brasileiro, a abrangência da televisão é muito maior do que a dos demais meios de comunicação, em razão do perfil dos 115,2 milhões de eleitores. Mais da metade do eleitorado, $58 \%$, tem até oito anos de estudo e renda familiar de até cinco salários mínimos, $70 \%$ (Tabela 4). A televisão cobre 99,86\% do território nacional e está presente em $87,7 \%$ dos domicílios, de acordo com o Mídia Dados 2001. O grande interesse pela televisão reflete o fato de ser ela a única opção de lazer e informação para parcela expressiva da população. Se comparada com as tiragens de revistas (a maior revista semanal, Veja, consegue vender pouco mais de 1,1 milhão) e dos maiores jornais (em torno de 400 mil exemplares), sua capacidade de influência fica ainda mais visível. No que diz respeito à concorrência entre as redes, o poder da Rede Globo é notável: $44 \%$ dos brasileiros (de um universo de 40,5 milhões de domicílios que possuem o aparelho no país) costumam assistir aos programas da emissora. 
OPINIÃO PÚBLICA, Campinas, Vol. IX, n², Outubro, 2003, pp. 93-117

Tabela 4

Perfil da amostra para pesquisa quantitativa, IBOPE 2002

\begin{tabular}{|l|c|}
\hline \multicolumn{2}{|c|}{ Nível educacional } \\
\hline Até $4^{a}$ série do fundamental & $33 \%$ \\
\hline $5^{a}$ a 8a série do fundamental & $25 \%$ \\
\hline Ensino médio & $32 \%$ \\
\hline Superior e mais & $10 \%$ \\
\hline \multicolumn{1}{|c|}{ Renda } \\
\hline Até um salário mínimo & $15 \%$ \\
\hline Mais de um a dois salários mínimos & $23 \%$ \\
\hline Mais de dois a cinco salários mínimos & $32 \%$ \\
\hline Mais de cinco a dez salários mínimos & $15 \%$ \\
\hline Mais de dez salários mínimos & $9 \%$ \\
\hline Não declarada & $5 \%$ \\
\hline \multicolumn{1}{|c|}{ Distribuição Geográfica } \\
\hline Norte/Centro-Oeste & $13 \%$ \\
\hline Nordeste & $27 \%$ \\
\hline Sudeste & $45 \%$ \\
\hline Sul & $15 \%$ \\
\hline \multicolumn{2}{|c|}{ Porte do Município } \\
\hline Até 20.000 habitantes & $30 \%$ \\
\hline Mais de 20.000 a 100.000 habitantes & $20 \%$ \\
\hline Mais de 100.000 habitantes & $50 \%$ \\
\hline Fonte: & \\
\hline
\end{tabular}

Fonte: Ibope.

Essa disseminação da televisão tem implicações sobre os comportamentos social e político. A televisão impõe muitas limitações à comunicação e pode construir a realidade de modo a ocultar o que é realmente importante (BOURDIEU, 1997). As restrições em relação ao que é mostrado pelas emissoras também são abordadas por Thompson (1998), que argumenta que os receptores não têm nenhum controle sobre o que é mostrado, o que pode causar distorções.

Em relação a seus efeitos sobre a política, pode-se retomar Mungham (1996), para quem a presença das câmeras é capaz de mudar o comportamento dos políticos e partidos, visto que estes são plenamente conscientes da força das imagens veiculadas pela televisão. A força televisiva evidencia que ingressamos na 
era do "videopoder" (SARTORI, 1995) ou ainda no que Rubim (1994) denomina como sendo a era de uma "televivência". Destacam-se, nestes exemplos, os possíveis efeitos da televisão na esfera social. Dentro desta perspectiva, aquilo que não é mostrado na televisão não ganha relevância social e nem é percebido pelos indivíduos em seu conjunto.

Essas análises contribuem para compreender a força e influência da televisão nas eleições brasileiras de 2002, a partir da expressiva movimentação havida depois dos programas partidários e após o início do horário eleitoral gratuito.

\section{Propaganda eleitoral e pesquisas}

A propaganda eleitoral gratuita marcou, de um lado, a consolidação da liderança de Lula, que esteve próximo de vencer no primeiro turno e, de outro lado, a disputa ferrenha entre José Serra e Ciro Gomes pelo segundo lugar. Além disso, foi acompanhada por uma novidade trazida pela Folha de S. Paulo, qual seja, a divulgação de pesquisas que mostravam como os eleitores estavam avaliando o que assistiam pela televisão.

De acordo com pesquisas realizadas pelo Instituto Datafolha, o interesse pelo horário eleitoral entre os brasileiros havia aumentado. Em 1998, 57\% diziam que pretendiam assisti-lo e 33\% diziam que este era muito importante para decidir o voto para presidente. Em 2002, estes percentuais subiram para $68 \%$ e $44 \%$, respectivamente.

O horário gratuito político eleitoral (HGPE) foi veiculado em dois períodos (de 20 de agosto a 03 de outubro, antes do $1^{\circ}$ turno, e de 14 a 25 de outubro, antes do $2^{\circ}$ turno). O critério para a divisão do tempo de cada candidatura na TV foi o da representação das coligações na Câmara dos Deputados. Neste aspecto, José Serra levava nítida vantagem sobre os demais, ficando com quase metade do horário destinado aos candidatos.

\section{Tabela 5}

Distribuição do uso do tempo dos candidatos na televisão

\begin{tabular}{|c|c|c|c|c|}
\hline Candidato & Coligação & Deputados & Tempo & Comerciais* $^{*}$ \\
\hline José Serra & PSDB-PMDB & 182 & $10,23 \mathrm{~min}$ & 225 \\
\hline Lula & PT.PL-PC do B.PMN & 80 & $5,19 \mathrm{~min}$ & 115 \\
\hline Ciro Gomes & PPS.PTB. PDT & 59 & $4,17 \mathrm{~min}$ & 93 \\
\hline Garotinho & PSB.PST-PDC & 19 & $2,13 \mathrm{~min}$ & 49 \\
\hline
\end{tabular}

Fonte: TSE e Folha de S. Paulo (18/08/2002). * Inserções de 30 segundos em horários diversos da programação regular das emissoras de rádio e televisão. 
Mais uma vez, o horário eleitoral influiu muito na decisão dos eleitores. As oscilações de intenção de voto após o início da propaganda gratuita foram notáveis. De 20 de agosto a 05 de outubro de 2002, Lula cresceu 11 pontos percentuais, Serra cresceu 8 pontos, Garotinho 4 pontos, enquanto Ciro Gomes teve uma queda de 18 pontos.

Tabela 6

Oscilação da pontuação dos candidatos no HGPE

\begin{tabular}{|c|c|}
\hline Candidato & Oscilação no H.G.P.E. (20/08 a 4-5/10) \\
\hline Lula & +11 \\
\hline Ciro & -18 \\
\hline Serra & +8 \\
\hline Garotinho & +4 \\
\hline
\end{tabular}

\section{Gráfico 6}

Intenções de voto para os candidatos à Presidência no período do HGPE (\%)

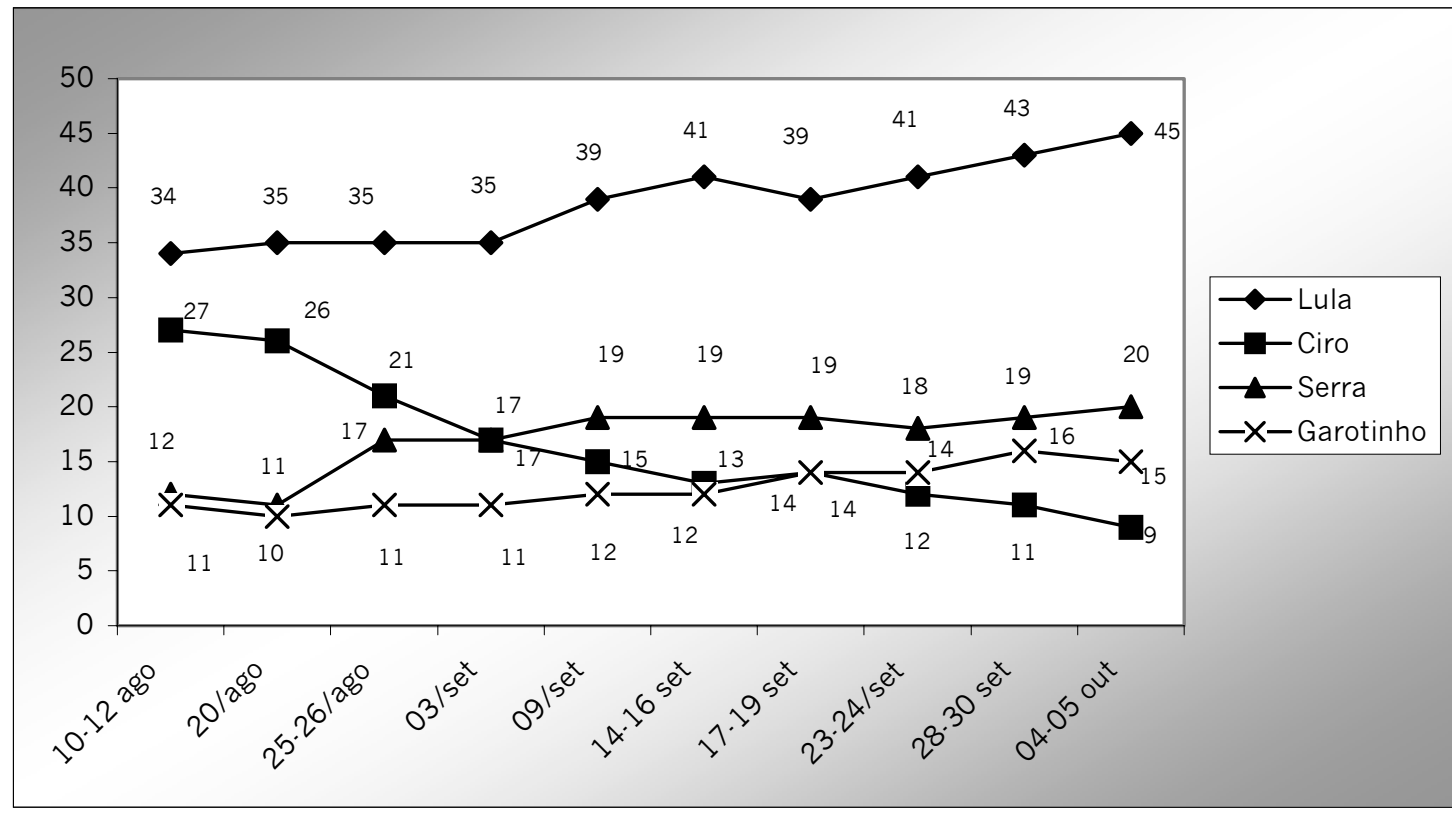

Fonte: Ibope 
A medição da opinião dos brasileiros sobre as propagandas foi realizada pelo Instituto Datafolha de duas maneiras. A primeira perguntava tão-somente como os eleitores ${ }^{2}$ avaliavam os comerciais (ótimo, bom, regular, ruim ou péssimo). A segunda forma de medição baseou-se em três índices: Índice de Aprovação da Propaganda (IAP), Índice de Imagem Positiva (IIP) e de Melhor Propaganda (MP). Ao todo, o jornal Folha de S. Paulo divulgou 19 de cada um dos índices. Essas avaliações seguiram, em largos traços, as oscilações dos principais candidatos nas sondagens de intenção de voto, conforme observamos a seguir, no cruzamento das informações das pesquisas de intenção de voto do Ibope e dos índices de Melhor Propaganda (MP), aferidos pelo Datafolha.

\section{Gráfico 7}

\section{Avaliação da Propaganda x Intenção de voto em Lula (\%)}

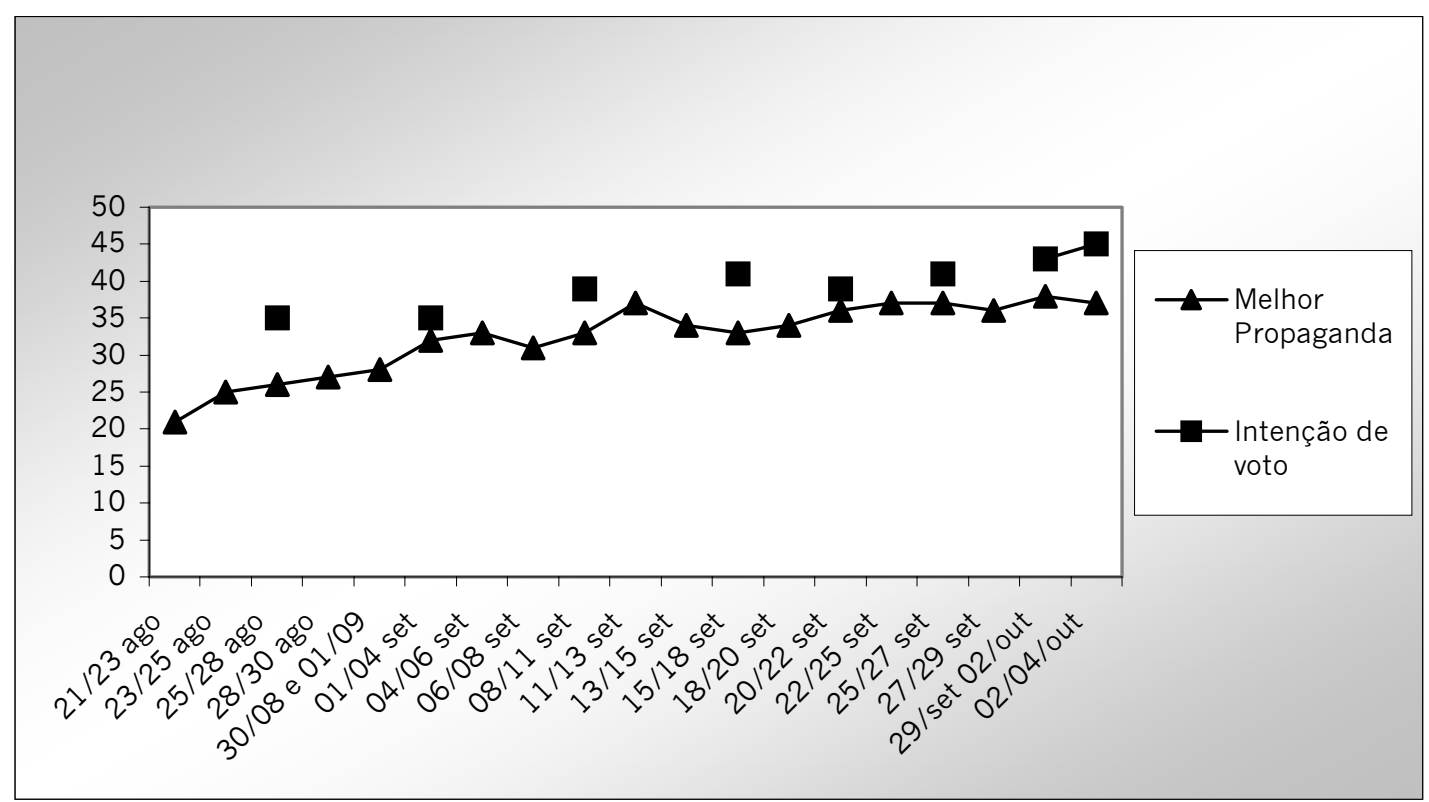

Fontes: Datafolha e Ibope. 2 Os respondentes desta pesquisa eram os eleitores que possuíam linha telefônica fixa, ou seja, $54 \%$ do
eleitorado. 


\section{Gráfico 8}

Avaliação da propaganda x Intenção de voto em Serra (\%)

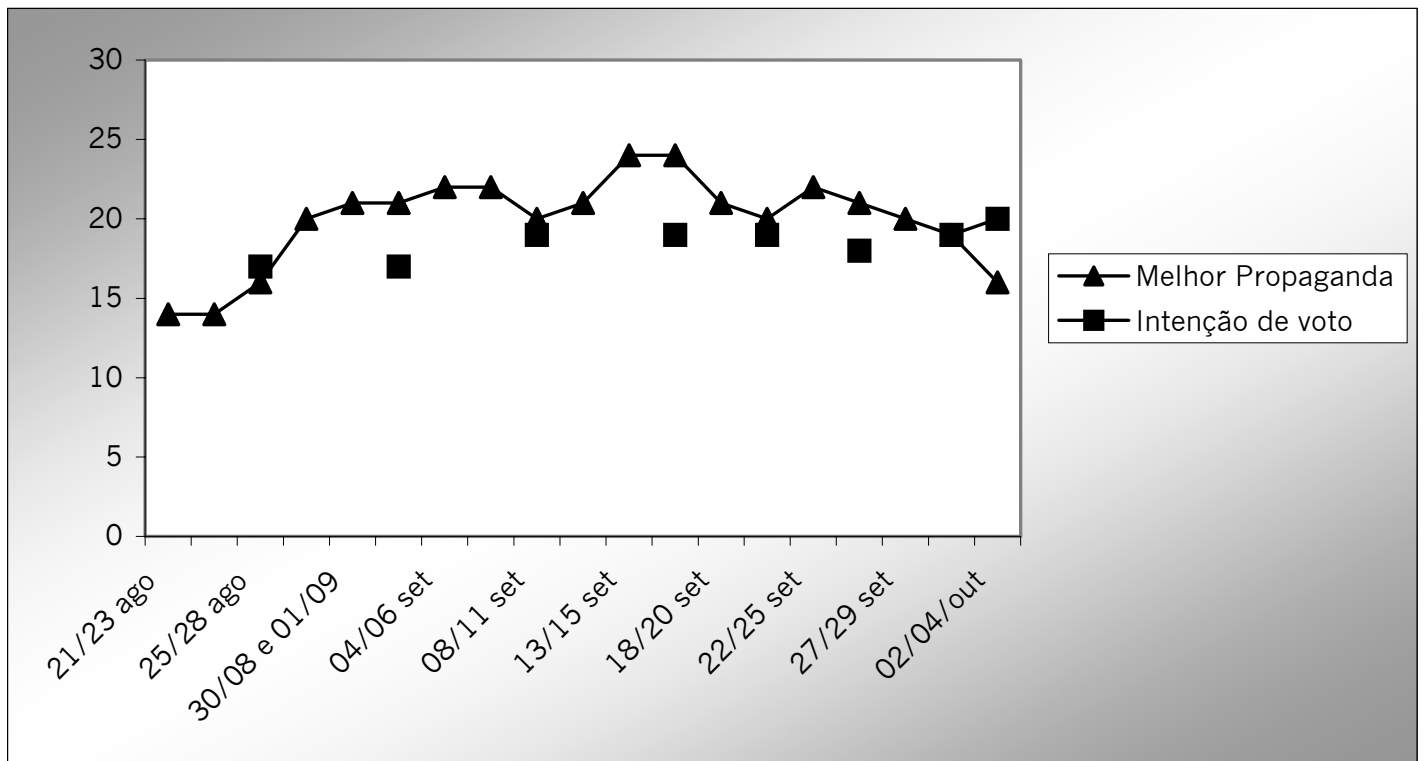

Fontes: Datafolha e Ibope.

\section{Gráfico 9}

\section{Avaliação da propaganda x Intenção de voto em Ciro (\%)}

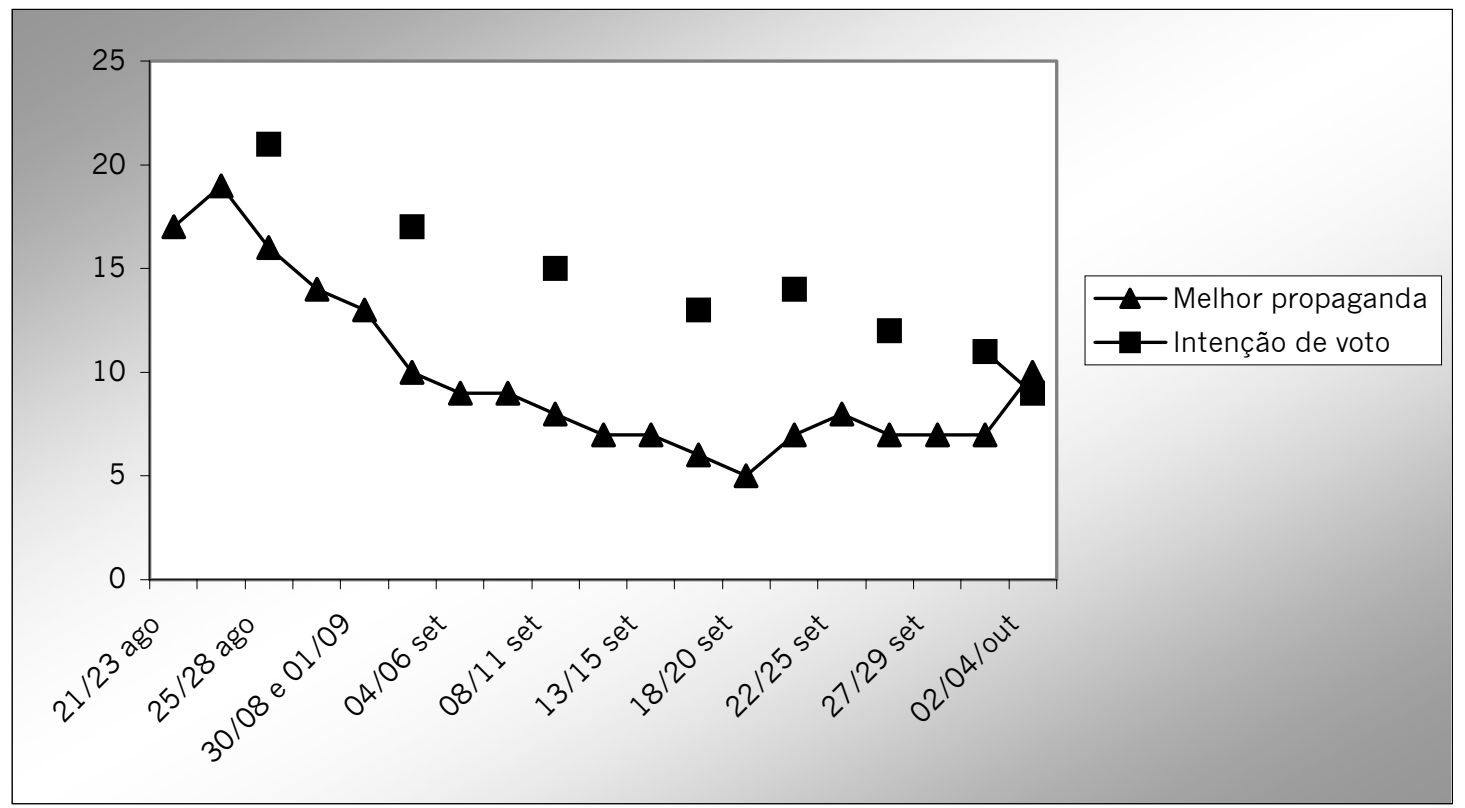

Fontes: Datafolha e Ibope. 


\section{Gráfico 10}

Avaliação da propaganda x Intenção de voto em Garotinho (\%)

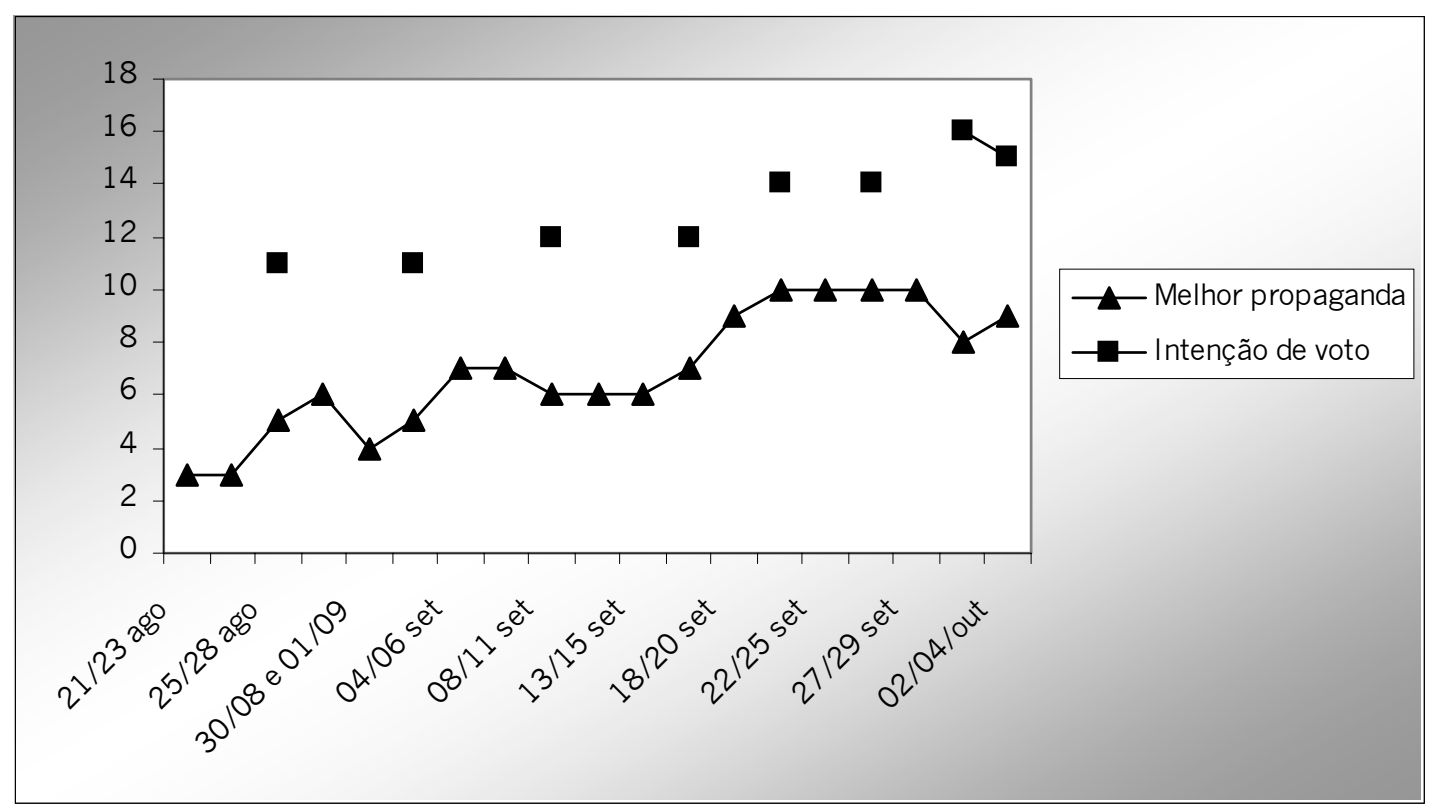

Fontes: Datafolha e Ibope.

O candidato Lula começou bem avaliado em todas as medições e melhorou ainda mais no decorrer dos períodos de propaganda eleitoral gratuita. Na média, manteve seus programas avaliados como "ótimos/bons" por cerca de $70 \%$ dos entrevistados durante todo o primeiro turno. José Serra conseguiu sair do incômodo terceiro lugar a partir do momento em que sua propaganda passou a ser melhor avaliada do que a de Ciro Gomes. Este, por sua vez, não conseguiu reagir e terminou a eleição em quarto lugar. Anthony Garotinho não teve variação expressiva na avaliação de sua propaganda que, apenas nos últimos dias, passou a apresentar uma aprovação semelhante à do candidato do PPS. 


\section{O caderno Folha Eleições e a controvérsia sobre a publicação de pesquisas}

O efeito sobre as escolhas eleitorais causado pela publicação de pesquisas é objeto de controvérsias entre os analistas. Steinberger, por exemplo, acredita que a publicação de resultados de sondagens pode influenciar o voto da parcela indecisa do eleitorado. Ela afirma que "as pesquisas são o instrumento para fomentar o jogo das torcidas" e que, dependendo das circunstâncias, a mídia pode "fabricar" a vitória de certos candidatos (STEINBERGER, 1998, p.40).

Silveira (1998) relativiza esta importância e destaca que existem outros fatores de influência sobre o voto, além das pesquisas eleitorais. Este autor questiona, inclusive, o fato de que os eleitores de menor renda e escolaridade sejam mais crédulos em relação às sondagens do que outros segmentos da população. Em relação à mídia, ele afirma que esta, "através de seus agentes, faz uma leitura da realidade, ao selecionar fatos considerados relevantes e ao interpretar estes fatos. Essa leitura da realidade veiculada pela mídia é, por sua vez, lida e interpretada, reconstruída pelos eleitores, de acordo com suas referências valorativas e simbólicas" (SILVEIRA, 1998, p.113).

Muitas vezes, mais do que pelo resultado efetivo da pesquisa, o eleitor é influenciado pela forma através da qual ele é divulgado. A imprensa, de maneira geral, tem fascinação por resultados de sondagens que apresentem alterações significativas no posicionamento dos candidatos. Desta forma, oscilações dentro da margem de erro em índices de intenção de voto podem, eventualmente, ser divulgadas como grandes quedas ou ascensões. Outro aspecto é que os programas eleitorais gratuitos dos candidatos, que têm altíssima audiência, também divulgam os resultados dos levantamentos com o objetivo de dar grande publicidade a eventuais dados positivos (CAVALLARI e OLSEN, 1993). A partir desses elementos, pode-se especular também se existe uma relação entre o posicionamento dos candidatos nas sondagens e o espaço que a imprensa Ihes proporciona.

O caderno Folha Eleições, publicado pelo jornal Folha de S. Paulo entre 18 de agosto e 29 de outubro de 2002, pode fornecer algumas pistas a este respeito. Foram ao todo 72 edições, sendo 4 delas duplas (dos dias 5,6 e 27 e 28 de outubro): nos dias das votações, um suplemento dedicado à cobertura do pleito presidencial e outro ao estadual, com as previsões dos institutos e nos dias seguintes às eleições, os primeiros resultados apurados, publicados novamente em dois suplementos. 
Entre os dias 18 de agosto e 6 de outubro, data de realização do primeiro turno das eleições, as primeiras 50 edições do suplemento destacaram em suas manchetes da primeira página os seguintes temas: 1) resultados de pesquisas (11 chamadas, sendo 6 sobre a sucessão presidencial e 5 sobre a estadual em São Paulo); 2) Lula e o PT (9 referências); 3) governo Fernando Henrique e o cenário para seu sucessor (8); 4) disputa entre Ciro Gomes e José Serra (7); 5) campanha do candidato Ciro Gomes (5); 6) disputa entre Lula e Serra (5); 7) campanha de José Serra (3); 8) sucessão estadual no Acre (1) e 9) propaganda eleitoral na televisão (1). É claro que, em alguns casos, as matérias abordavam mais de um destes temas simultaneamente ${ }^{3}$. Essa classificação serve como um índice dos assuntos mais freqüentes abordados pelo caderno conforme os temas aqui analisados ${ }^{4}$.

Ainda sobre o formato e os temas tratados pelo suplemento Folha Eleições, devemos destacar a presença dos candidatos nas principais matérias da primeira página. Somadas aquelas sobre as campanhas dos candidatos e as que tratavam de suas disputas com os adversários (excluindo-se as que abordam os resultados de pesquisas, que são um caso à parte na cobertura), José Serra teve seu nome mencionado em 15 matérias, Lula em 14 e Ciro Gomes em 12. Garotinho só apareceu em duas delas, e de forma secundária. Também pôde-se perceber que a aparição de Ciro Gomes nas manchetes foi mais freqüente enquanto o candidato estava bem posicionado nas pesquisas. Após ser ultrapassado por José Serra nas sondagens, o ex-governador do Ceará sumiu das manchetes principais do Folha Eleições. Em resumo, 31 das 50 manchetes principais do caderno (até dia 6 de outubro) traziam notícias sobre os candidatos, o que significa $62 \%$ do total.

O papel das pesquisas enquanto instrumento também foi objeto de destaque do caderno. Foram 11 manchetes destacando as sondagens, além da colocação, nas páginas internas do caderno, de tabelas detalhando alguns dos segmentos pesquisados e os resultados das pesquisas do Datafolha e de outros institutos, como Sensus, Vox Populi e Ibope. Quanto ao destaque dado aos candidatos à Presidência, o fato de apenas alguns serem mencionados no caderno, ou seja, apenas aqueles com maiores intenções de voto, demonstra a relação positiva entre resultados das pesquisas e o espaço obtido pelos candidatos na imprensa.

\footnotetext{
${ }^{3}$ É preciso ressalvar que o jornal Folha de S. Paulo conta com um instituto de pesquisa próprio, o Datafolha. A linha editorial privilegia a divulgação e análise dos resultados das pesquisas deste Instituto.

${ }^{4}$ As 22 manchetes restantes (de 07 a 29 de outubro) não são tratadas por este artigo porque se referem ao segundo turno, onde já havia uma polarização definida entre Lula (PT) e Serra (PSDB), o que restringiu as possibilidades de abordagem da campanha a estes candidatos e partidos.
} 
O impacto dos resultados das pesquisas sobre as menções aos candidatos nas manchetes principais do caderno mostrou três tendências: a presença constante de notícias envolvendo José Serra; a grande freqüência de aparições do nome de Ciro Gomes enquanto este ocupou o segundo lugar e a presença irregular de noticiário sobre Lula. Vale lembrar que o candidato Ciro Gomes ganhou espaço também em razão de uma série de declarações polêmicas.

Isso sugere que as pesquisas não influenciaram apenas a estratégia das campanhas e o voto dos eleitores (embora, neste último caso, não se possa comprovar em que grau isso ocorre), mas também influenciaram os jornalistas e a cobertura da mídia. A Tabela 7, a seguir, mostra a variação no número de aparições dos candidatos no caderno Folha Eleições nos dias posteriores à divulgação dos números do Instituto Datafolha.

Gráfico 11

Intenção de voto para os candidatos à Presidência (\%)

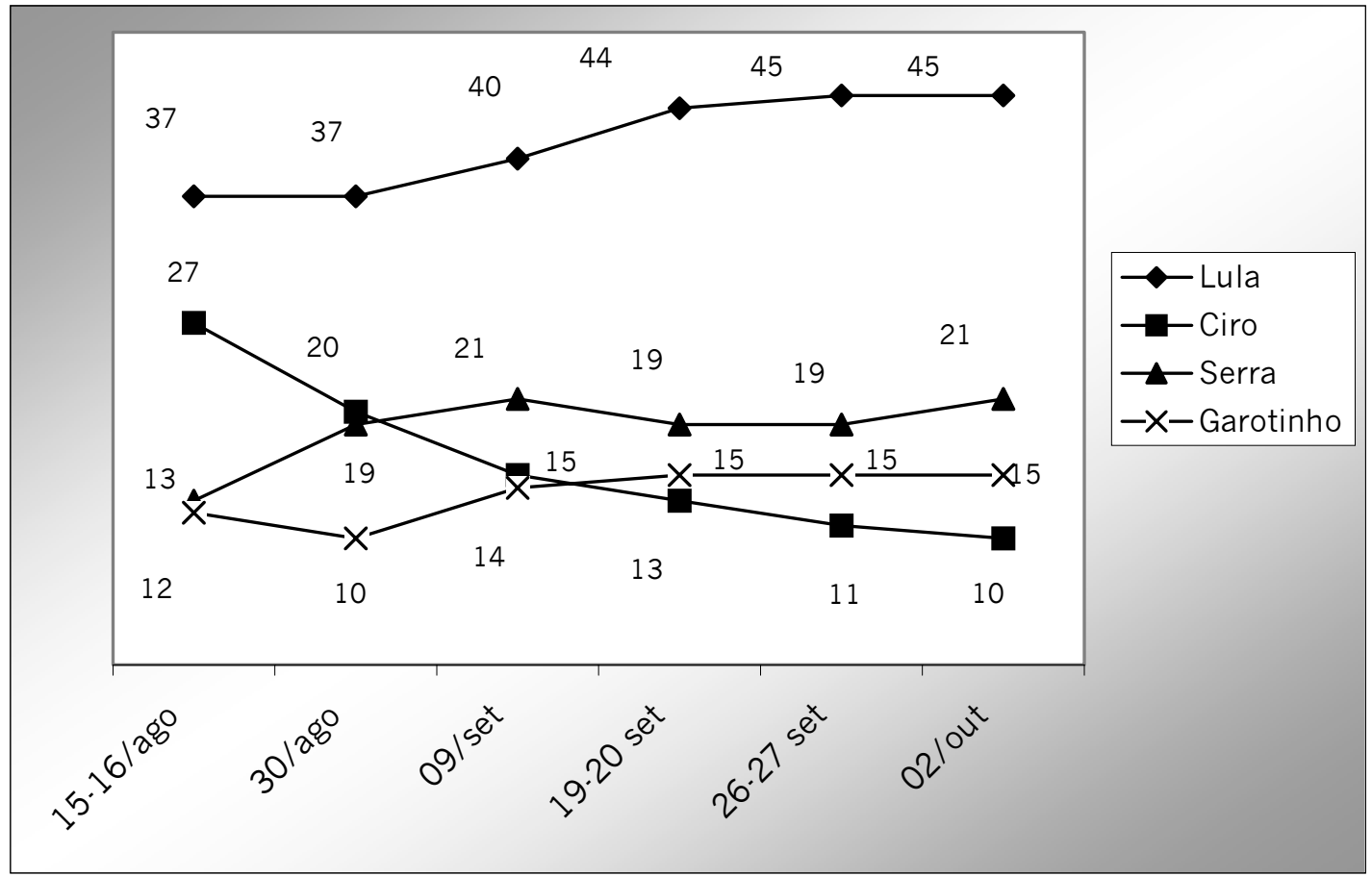

Fonte: Datafolha. 
Tabela 7

Número de menções aos candidatos nas manchetes dos dias posteriores à divulgação das pesquisas

\begin{tabular}{|c|c|c|c|}
\hline $\begin{array}{c}\text { Data de divulgação da } \\
\text { pesquisa }\end{array}$ & Serra (PSDB) & Ciro (PPS) & Lula (PT) \\
\hline $18 / 08 / 02$ & 6 & 9 & 1 \\
\hline $01 / 09 / 02$ & 3 & 4 & 2 \\
\hline $10 / 09 / 02$ & 4 & 2 & 5 \\
\hline $22 / 09 / 02$ & 2 & 0 & 2 \\
\hline $29 / 09 / 02$ & 1 & 0 & 1 \\
\hline $03 / 10 / 02$ & 1 & 0 & 2 \\
\hline
\end{tabular}

Fonte: Folha Eleições.

Em que pese a influência das pesquisas, os principais destaques do caderno Folha Eleições parecem confirmar a idéia de que os jornalistas são construtores da realidade pública e não apenas meros espectadores que retransmitem os fatos tal "como eles são" (ALSINA, 1989). Nesse sentido, o jornalista deve ser compreendido como produtor da realidade social, o que se choca frontalmente com a idéia tradicional de objetividade jornalística.

\section{A estratégia dos candidatos e o marketing político}

O destaque conferido às estratégias de marketing político ajudou a reforçar ainda mais o papel das pesquisas nas campanhas dos principais candidatos, como já havia acontecido nas eleições presidenciais anteriores. O "marketeiro" de Lula sabia disso $0^{5}$ e, aparentemente, soube utilizar melhor este recurso para transformar seu candidato no grande vencedor.

Conforme as pesquisas indicavam, a maior parte do eleitorado estava disposta a votar em um candidato que representasse uma mudança nos rumos políticos do país. Este clima de opinião favorecia os candidatos de oposição, em especial Lula, que havia mantido uma posição crítica em relação ao governo FHC durante os 8 anos desta gestão.

\footnotetext{
${ }^{5}$ Ver, a respeito da importância das pesquisas numa campanha eleitoral, MENDONÇA (2001).
} 
Entretanto, apenas isso não bastaria para assegurar a vitória ao candidato do PT. Lula, que já havia sido derrotado em três eleições presidenciais sucessivas e era por isso estigmatizado - como também por sua inexperiência administrativa, por sua imagem solidificada como líder radical de esquerda, promotor de greves e por não ter diploma de ensino superior - precisava ainda mostrar como pretendia governar o Brasil num cenário complexo, marcado por crises sucessivas nos mercados financeiros internacionais.

A estratégia de marketing político do candidato encontrou como solução mostrar um Lula conciliador, trajado de modo elegante e amparado por uma equipe de estudiosos e técnicos de grande qualidade. O candidato Lula mostrava-se disposto a continuar com as linhas principais da política econômica ${ }^{6}$ e cumprir contratos assumidos com investidores estrangeiros; mostrava ainda que saberia ser flexível e negociar tudo que fosse necessário para o bem do país. Tudo isso com o auxílio de especialistas do partido que, de certa forma, compensariam a falta de preparo acadêmico e prático do próprio candidato. Além disso, segundo pesquisas qualitativas indicavam, os eleitores viam em Lula alguém que poderia dar atenção aos temas sociais e governar com mais "garra" e "emoção" (CARRO e FELíclO, 2002).

Esta estratégia deu certo não apenas porque conseguiu diminuir a rejeição ao candidato, mas também porque Lula quase não foi atacado antes do primeiro turno. A briga entre Serra e Ciro pelo segundo lugar e a garantia de que o petista iria ao segundo turno não apenas pouparam Lula como o ajudaram a quase vencer na primeira votação.

José Serra, por sua vez, realizou um percurso bem mais tortuoso até chegar ao segundo turno das eleições de 2002. Primeiro, teve que vencer as disputas internas de seu partido, o PSDB, e por não ser unanimidade, recebeu críticas e perdeu apoio interno. Apesar disso, contava com aspectos favoráveis: a aliança com o PMDB garantiu-Ihe o maior tempo no horário eleitoral, o candidato tinha simpatia de grande parte do empresariado, melhor preparo acadêmico do que Lula e experiência administrativa adquirida após a passagem por vários cargos executivos, entre eles o Ministério da Saúde. Deste último, saiu reconhecido pela população como corajoso e realizador, por ter conseguido implantar a legislação sobre os medicamentos genéricos no país e por fazer do Brasil referência internacional no tratamento da AIDS.

\footnotetext{
${ }^{6}$ Nas eleições de 1994, o PT havia classificado o Plano Real como estelionato eleitoral.
} 
As pesquisas qualitativas detectavam, porém, dois pontos negativos com relação a José Serra: o fato do político não transmitir simpatia e representar a continuidade do governo FHC (CARRO e FELÍCIO, 2002). É possível que esta constatação das sondagens tenha norteado a campanha de Serra e feito com que ele se apresentasse como o "candidato da mudança", discurso que se revelou pouco convincente, já que o eleitorado identificava o tucano com o governo. Se alguém mudaria o país, esse alguém seria Lula.

Outra dificuldade de Serra foi ter que disputar, não sem desgaste para sua candidatura, o segundo lugar com Ciro Gomes. O ex-colega de partido tinha, segundo o lbope, 15 pontos de vantagem sobre o tucano quando a propaganda eleitoral começou. Neste caso, porém, a estratégia foi bem sucedida. A campanha do PSDB conseguiu mostrar Ciro como um político emocionalmente desequilibrado, inábil para negociar, que explicava mal suas propostas e se contradizia com freqüência.

Após estabilizar-se no segundo lugar, José Serra passou a atacar Lula em seus pontos fracos. Assim, no curto espaço de tempo até o segundo turno, a estratégia do tucano concentrou-se em afirmar que Lula não queria debater porque não tinha preparo e tentar incentivar um certo temor sobre possíveis conseqüências da vitória do PT, tais como a fuga de investimentos estrangeiros, o descontrole da inflação etc. Estes ataques não tiveram, porém, o efeito desejado e o petista quase venceu as eleições no primeiro turno.

Ciro Gomes, o último a aparecer nas propagandas partidárias gratuitas na televisão antes do início oficial da campanha, tinha a imagem de um político experiente, preparado intelectualmente e firme nas decisões. Os ataques de Serra, entretanto, contribuíram para que o eleitorado mudasse de opinião. Suas explicações empoladas e técnicas sobre seu plano de governo - incompreensíveis para uma parcela expressiva da população de baixa escolaridade - e a reação agressiva às críticas que sofria contribuíram para solidificar a imagem de um político de "pavio curto". Ciro perdeu apoios políticos, caiu nas pesquisas e terminou em quarto lugar. 
Anthony Garotinho, por fim, trocou uma reeleição certa como governador do Rio de Janeiro pela disputa presidencial. A concentração de seus votos em seu estado natal, o relativo desconhecimento em nível nacional, o uso excessivo da religião na campanha, a falta de espaço na imprensa e a perda de apoio dentro de seu próprio partido desde o início do ano dificultaram sua performance. Nos últimos dias, com o desgaste de Serra e a queda acentuada de Ciro, a campanha de Garotinho alcançou maior destaque e fez com que ele terminasse a disputa presidencial em terceiro lugar.

Quando se observam as estratégias utilizadas pelos candidatos durante o horário eleitoral gratuito e também o que as pesquisas indicavam, a vitória de Lula nos dois turnos não foi surpresa. O candidato do PT obteve $46,4 \%$ dos votos válidos no primeiro turno, enquanto os institutos de pesquisa previam uma votação entre $48 \%$ e $50 \%$ dos votos e, no segundo turno, obteve $61,3 \%$ dos votos válidos, sendo que a previsão era de $63 \%$.

\section{Bibliografia}

ALSINA, Miquel Rodrigo. La construcción de la noticia. Paidós Comunicación, Barcelona/Buenos Aires/México, 34, 1989.

BORDIEU, Pierre. Sobre a televisão. São Paulo: Jorge Zahar Editor, 1997, p. 19-24.

BUCCI, Eugênio. A metapublicidade e Roseana Sarney. Folha de S. Paulo, TV Folha, São Paulo, p.2, 18 nov. 2001.

CARRO, Rodrigo e FELÍCIO, César. Qualitativas norteiam horário eleitoral. Jornal Valor Econômico, São Paulo, p. A.8 ,22 ago.2002.

CAVALLARI NUNES, Marcia; OLSEN, Örján; STRAUBHAAR, Joseph. O uso de pesquisas eleitorais em decisões de voto. Opinião Pública, Campinas, vol. I, n², p. 47-96, dez. 1993.

FREITAS, Jânio de. A nova trapaça. Folha de S. Paulo, São Paulo, p.A-5, 21 jul. 2002.

LAMOUNIER, Bolivar e FIGUEIREDO, Rubens (orgs.). A era FHC - um balanço. São Paulo: Cultura Editores Associados, 2002. 
LOURENÇO, Luiz Cláudio. HGPE e Intenção de voto: observações sobre as eleições de 1998 ao governo de São Paulo e à Presidência da República. In: XI Congresso dos Sociólogos do Estado de São Paulo, 04 out. 2001, São Paulo. Paper, PUC.SP.

MATTOS, Laura. A festa é nossa. Folha de S. Paulo, São Paulo, p.E-1, 30 out.2002.

MENDONÇA, Duda. Casos \& coisas. São Paulo: Globo, 2001.

MUNGHAM, Geoff. A batalha pelo controle da agenda: a mídia, os políticos e o processo eleitoral na Grã-Bretanha. Comunicação e Política, vol. III, n², CEBELA, mai-ago. 1996.

RUBIM, Antonio Albino Canelas. Mídia, política e democracia. Textos de Cultura e Comunicação. Salvador, Fase II, números 31-32, 1994.

SARTORI, Giovanni. Videopoder. In Elementos de Teoria Política. Madrid: Alianza Editorial, p. 305-316, 1995.

SILVEIRA, Flávio Eduardo. A decisão do voto no Brasil. Porto Alegre: EDIPUCRS, 1998.

STEINBERGER, Margarethe Born. Desmidiatizar o pensamento. São Paulo em Perspectiva, São Paulo, 12(4),1998.

THOMPSON, J.B. A mídia e a modernidade: uma teoria social da mídia. Petrópolis: Editora Vozes, 1998. 